\title{
PEMODELAN INDEKS HARGA SAHAM GABUNGAN MENGGUNAKAN REGRESI SPLINE MULTIVARIABEL
}

\author{
Ihdayani Banun Afa ${ }^{1}$, Suparti, Rita Rahmawati ${ }^{3}$ \\ 1,2,3 Departemen Statistika, Fakultas Sains dan Matematika, Universitas Diponegoro \\ e-mail : suparti702@gmail.com
}

\begin{abstract}
The Composite Stock Price Index (CSPI) is a composite index of all types of shares listed on the stock exchange and their movements indicate the conditions occurring in the stock market. CSPI movement is an important indicator for investors to determine whether they will sell, hold, or buy a stock. One of the factors that influence the movement of CSPI is Inflation $\left(\mathrm{X}_{1}\right)$, Exchange Rate $\left(\mathrm{X}_{2}\right)$ and SBI rate $\left(\mathrm{X}_{3}\right)$. This study aims to obtain the best CSPI model using a multivariable nonparametric spline regression approach. The approach is done by nonparametric regression because the regression curve obtained does not show a certain relationship pattern. Spline is very dependent on the order and location of the knot point. The best spline model is the model that has the minimum MSE (Mean Square Error) value. In this study, the best spline regression model is when $\mathrm{X}_{1}$ is 4 order, $X_{2}$ is 2 order and $X_{3}$ is 2 order. The number of knots on $X_{1}$ is 1 knot at $8.22, X_{2}$ is 2 knots at 13066.82 and 13781.75 While $\mathrm{X}_{3}$ is 2 knots at 6.6 and 6.67 with value of MSE equal to 6686.85.
\end{abstract}

Keywords: Composite Stock Price Index, Multivariable Spline Regression, MSE

\section{PENDAHULUAN}

Keberadaan pasar modal di Indonesia merupakan salah satu faktor penting dalam pembangunan perekonomian nasional. Salah satu indikator utama yang mencerminkan kinerja pasar modal di Indonesia saat sedang mengalami peningkatan atau sedang mengalami penurunan adalah indeks harga saham gabungan (IHSG). Menurut Wijaya (2015), pergerakan IHSG sangat dipengaruhi oleh beberapa faktor baik dari dalam negeri (internal) maupun dari luar negeri (eksternal). Faktor-faktor internal tersebut berasal dari kurs valuta asing, tingkat pendapatan nasional, jumlah uang yang beredar, tingkat inflasi, dan tingkat suku bunga domestik pada negara tersebut. Sedangkan, faktor-faktor eksternal dapat berasal dari indeks bursa efek di negara lain (seperti indeks Dow Jones, FTSE 100, NIKKEI 225, Han Seng), harga minyak mentah dunia, harga emas dunia, dan berbagai peristiwa politik yang mempengaruhi keamanan dan stabilitas perekonomian dunia.

Salah satu metode statistika yang bisa menjelaskan hubungan antara antara variabel prediktor terhadap variabel respon adalah analisis regresi. Analisis regresi yang sering digunakan adalah analisis regresi parametrik. Pendekatan regresi secara parametrik membutuhkan asumsi-asumsi yang harus dipenuhi untuk menghasilkan pemodelan yang baik. Pendekatan regresi parametrik menghasilkan model yang baik jika bentuk kurva regresinya diketahui. Regresi nonparametrik digunakan jika bentuk kurva fungsinya tidak diketahui sehingga data akan mencari sendiri bentuk kurva regresinya. Kurva regresi hanya diasumsikan smooth (mulus) termuat di dalam suatu ruang fungsi tertentu. Sehingga, regresi nonparametrik memiliki fleksibilitas yang tinggi karena data diharapkan mencari sendiri bentuk estimasi kurva regresinya tanpa dipengaruhi oleh faktor subyektifitas peneliti (Eubank, 1999).

Salah satu metode regresi nonparametrik adalah spline. Spline adalah suatu pendekatan ke arah pencocokan data dengan tetap memperhitungkan kemulusan kurva. Spline mempunyai keunggulan dalam mengatasi pola data yang menunjukkan naik/turun yang tajam dengan bantuan titik-titik knot, serta kurva yang dihasilkan relatif mulus (Hardle, 1990). Pada analisis regresi nonparametrik spline jika terdapat satu variabel respon dan satu variabel prediktor maka regresi tersebut dinamakan regresi nonparametrik spline univariabel, sedangkan jika terdapat satu variabel respon dengan lebih dari satu variabel prediktor regresi nonparametrik spline multivariabel (Budiantara, 2005). Maka dalam penelitian ini akan dilakukan pemodelan 
IHSG menggunakan regresi spline multivariabel dengan inflasi, kurs dan suku bunga SBI sebagai variabel prediktornya.

\section{TINJAUAN PUSTAKA}

\subsection{Indeks Harga Saham Gabungan}

Menurut Samsul (2006), indeks harga saham gabungan (composite stock price index= CSPI) merupakan indeks gabungan dari seluruh jenis saham yang tercatat di bursa efek. Indeks berfungsi sebagai indikator tren pasar, artinya pergerakan indeks menggambarkan kondisi pasar pada suatu saat, apakah pasar sedang aktif atau lesu (Martalena dan Maya, 2011).

\subsection{Faktor yang Mempengaruhi IHSG}

\subsubsection{Nilai Tukar}

Menurut Salvatore (2014), nilai tukar (atau dikenal sebagai kurs) didefinisikan sebagai harga mata uang dalam negeri dari mata uang asing.

\subsubsection{Inflasi}

Menurut Yanuar (2013), inflasi merupakan kecenderungan meningkatnya tingkat harga secara umum dan terus-menerus. Kenaikan harga dari satu atau dua barang saja tidak disebut sebagai inflasi, kecuali bila kenaikan tersebut meluas ke sebagian besar harga barangbarang lain.

\subsubsection{Suku bunga SBI}

Menurut Astuti et al. (2013), suku bunga SBI merupakan salah satu mekanisme yang digunakan Bank Indonesia untuk mengontrol kestabilan nilai Rupiah.

\subsection{Regresi Nonparametrik}

Pendekatan nonparametrik merupakan metode pendugaan model yang dilakukan berdasarkan pendekatan yang tidak terikat asumsi bentuk kurva regresi tertentu.

Bentuk model regresi nonparametrik adalah sebagai berikut:

$$
y_{i}=f\left(x_{i}\right)+\varepsilon_{i}, i=1,2 \ldots n
$$

dengan $y_{i}$ adalah variabel respon, $f\left(x_{i}\right)$ merupakan fungsi regresi yang tidak diketahui bentuknya dan $\varepsilon_{i}$ adalah error random yang independen dengan mean 0 dan varian $\sigma^{2}$.

\subsection{Regresi Nonparametrik Spline}

Spline merupakan potongan (piecewise) polinomial tersegmen (truncated) yang kontinu, sehingga memiliki kemampuan menyesuaikan diri lebih efektif terhadap pola data yang naik atau turun secara tajam dengan bantuan titik-titik knot, serta kurva yang dihasilkan relatif mulus (Eubank, 1999). Secara umum fungsi spline polinomial truncated berorde $m$ dengan $r$ titik knot yaitu $\Pi=\left\{k_{1}, k_{2}, \ldots, k_{r}\right\}$ didefinisikan sebagai berikut:

$$
f(x)=\sum_{j=0}^{m-1} \beta_{j} x^{j}+\sum_{j=1}^{r} \beta_{j+m-1}\left(x-k_{j}\right)_{+}^{m-1}
$$

dengan fungsi truncated,

$$
\left(x-k_{j}\right)_{+}^{m-1}=\left\{\begin{array}{rr}
\left(x-k_{j}\right)^{m-1}, & x-k_{j} \geq 0 \\
0, & x-k_{j}<0
\end{array}\right.
$$


dan $\left(a<k_{1}<k_{2}<\cdots<k_{r}<b\right)$, dimana $a$ diambil dari nilai minimum $x$ dan $b$ diambil dari nilai maksimum $x$. Dengan koefisien $\beta_{j}$ merupakan konstanta yang bernilai real dengan $j=0,1, \ldots, m-1, m, \ldots, r+m-1$.

Dengan menggunakan data amatan sebanyak $n$, maka bentuk persamaan regresi spline dapat ditulis ke dalam matriks sebagai berikut:

dengan,

$$
Y=X_{1} \delta_{1}+X_{2} \delta_{2}+\varepsilon
$$

$$
\begin{gathered}
\boldsymbol{Y}=\left[\begin{array}{c}
y_{1} \\
y_{2} \\
\vdots \\
y_{n}
\end{array}\right] ; \quad \boldsymbol{X}_{\mathbf{1}}=\left[\begin{array}{cccc}
1 & x_{1} & \ldots & x_{1}^{m-1} \\
1 & x_{2} & \ldots & x_{2}^{m-1} \\
\vdots & \vdots & \ddots & \vdots \\
1 & x_{n} & \ldots & x_{n}^{m-1}
\end{array}\right] ; \quad \boldsymbol{\delta}_{\mathbf{1}}=\left[\begin{array}{c}
\beta_{0} \\
\beta_{1} \\
\vdots \\
\beta_{m-1}
\end{array}\right] \\
\boldsymbol{X}_{\mathbf{2}}=\left[\begin{array}{ccc}
\left(x_{1}-k_{1}\right)_{+}^{m-1} & \ldots & \left(x_{1}-k_{r}\right)_{+}^{m-1} \\
\left(x_{2}-k_{1}\right)_{+}^{m-1} & \ldots & \left(x_{2}-k_{r}\right)_{+}^{m-1} \\
\vdots & \ldots & \vdots \\
\left(x_{n}-k_{1}\right)_{+}^{m-1} & \cdots & \left(x_{n}-k_{r}\right)_{+}^{m-1}
\end{array}\right] ; \quad \boldsymbol{\delta}_{\mathbf{2}}=\left[\begin{array}{c}
\beta_{(m-1)+1} \\
\beta_{(m-1)+2} \\
\vdots \\
\beta_{(m-1)+r}
\end{array}\right] ; \quad \boldsymbol{\varepsilon}=\left[\begin{array}{c}
\varepsilon_{1} \\
\varepsilon_{2} \\
\vdots \\
\varepsilon_{n}
\end{array}\right]
\end{gathered}
$$

Bentuk matriks dari persamaan (4) regresi spline dapat ditulis sebagai berikut:

$$
\boldsymbol{Y}=\boldsymbol{X}_{\Pi} \boldsymbol{\beta}_{\Pi}+\boldsymbol{\varepsilon}
$$

dengan $\boldsymbol{X}_{\Pi}=\left[\begin{array}{ll}\boldsymbol{X}_{\mathbf{1}} & \boldsymbol{X}_{\mathbf{2}}\end{array}\right]$ dan $\boldsymbol{\beta}_{\Pi}=\left[\begin{array}{l}\boldsymbol{\delta}_{\mathbf{1}} \\ \boldsymbol{\delta}_{2}\end{array}\right]$, maka bentuk persamaan (4) menjadi:

$$
\left[\begin{array}{c}
y_{1} \\
y_{2} \\
\vdots \\
y_{n}
\end{array}\right]=\left[\begin{array}{ccccccl}
1 & x_{1} & \ldots & x_{1}^{m-1} & \left(x_{1}-k_{1}\right)_{+}^{m-1} & \ldots & \left(x_{1}-k_{r}\right)_{+}^{m-1} \\
1 & x_{2} & \ldots & x_{2}^{m-1} & \left(x_{2}-k_{1}\right)_{+}^{m-1} & \ldots & \left(x_{2}-k_{r}\right)_{+}^{m-1} \\
\vdots & \vdots & \cdots & \vdots & \vdots & \ldots & \vdots \\
1 & x_{n} & \cdots & x_{n}^{m-1} & \left(x_{n}-k_{1}\right)_{+}^{m-1} & \ldots & \left(x_{n}-k_{r}\right)_{+}^{m-1}
\end{array}\right]\left[\begin{array}{c}
\beta_{0} \\
\vdots \\
\beta_{m-1} \\
\beta_{(m-1)+1} \\
\vdots \\
\beta_{(m-1)+r}
\end{array}\right]+\left[\begin{array}{c}
\varepsilon_{1} \\
\varepsilon_{2} \\
\vdots \\
\varepsilon_{n}
\end{array}\right]
$$

Estimasi koefisien regresi $\boldsymbol{\beta}_{\Pi}$ dilakukan dengan menggunakan OLS (Ordinary Least Square) menghasilkan $\widehat{\boldsymbol{\beta}}_{\Pi}=\left(\boldsymbol{X}_{\Pi}^{\boldsymbol{T}} \boldsymbol{X}_{\Pi}\right)^{\mathbf{- 1}} \boldsymbol{X}_{\Pi}^{\boldsymbol{T}} \boldsymbol{Y}$.

\subsection{Regresi Nonparametrik Spline Multivariabel}

Model spline multivariabel dapat ditulis sebagai berikut:

$$
\begin{gathered}
y_{i}=f_{1}\left(x_{1 i}\right)+f_{2}\left(x_{2 i}\right)+\cdots+f_{p}\left(x_{p i}\right)+\varepsilon_{i}=y_{i}=\sum_{l=1}^{p} f_{l}\left(x_{l i}\right)+\varepsilon_{i} \\
\text { dengan } \quad f\left(x_{l i}\right)=\sum_{k=0}^{m_{l}-1} \alpha_{k l} x_{l i}^{k}+\sum_{j=1}^{r_{l}} \beta_{l j}\left(x_{l i}-k_{j l}\right)_{+}^{m_{l}-1}
\end{gathered}
$$

dengan fungsi truncated,

$$
\left(x_{l i}-k_{j l}\right)_{+}^{m_{l}-1}=\left\{\begin{aligned}
\left(x_{l i}-k_{j l}\right)^{m_{l}-1}, & x_{l i}-k_{j l} \geq 0 \\
0, & x_{l i}-k_{j l}<0
\end{aligned}\right.
$$

Fungsi penduga dari $f(x)$ untuk regresi spline multivariabel dengan $\mathrm{p}$ variabel prediktor, orde setiap variabel adalah $m_{l}$ dan banyaknya titik knot setiap variabel adalah $r_{l}$.

$$
\hat{f}_{\Pi}(x)=\boldsymbol{X}_{\Pi} \widehat{\boldsymbol{\beta}}_{\Pi}=\boldsymbol{X}_{\Pi}\left(\boldsymbol{X}_{\Pi}^{\boldsymbol{T}} \boldsymbol{X}_{\Pi}\right)^{-\mathbf{1}} \boldsymbol{X}_{\Pi}^{\boldsymbol{T}} \boldsymbol{Y}=\boldsymbol{H}_{\Pi} \boldsymbol{Y}
$$


dengan $\boldsymbol{H}_{\Pi}=\boldsymbol{X}_{\Pi}\left(\boldsymbol{X}_{\Pi}^{\boldsymbol{T}} \boldsymbol{X}_{\Pi}\right)^{-\mathbf{1}} \boldsymbol{X}_{\Pi}^{\boldsymbol{T}}$ matriks simetris dan definit positif (Eubank, 1999). Dengan $\boldsymbol{X}_{\Pi}$ adalah matriks desain berukuran ( $\left.n \times \mathrm{s}\right)$.

Dimana s adalah $1+\sum_{l=1}^{p}\left(m_{l}+r_{l}\right)-p$ dari model yang membentuk penduga $f_{\Pi}$ dan bergantung pada titik knot $\Pi=\left\{k_{11}, k_{21}, \ldots k_{r_{1} 1}, \ldots \ldots, k_{1 p}, k_{2 p} \ldots k_{r_{p} p}\right\}$.

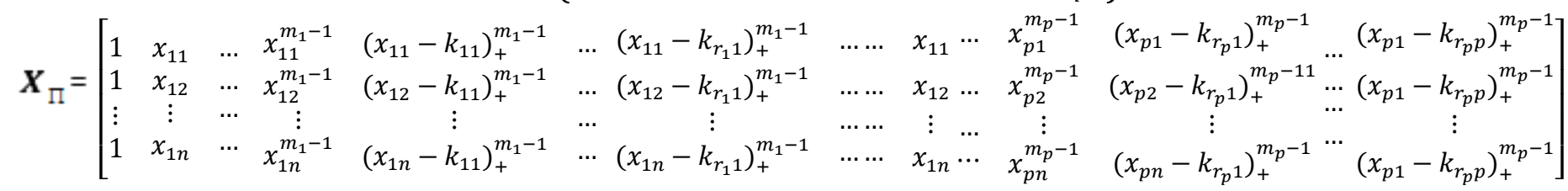

\subsection{Pemilihan Titik Knot Optimal}

Titik knot merupakan titik perpaduan bersama yang memperlihatkan terjadinya perubahan perilaku fungsi spline pada interval-interval yang berbeda (Budiantara, 2005). Untuk mendapatkan spline optimal perlu dipilih banyaknya titik-titik knot dan letak titik-titik knot yang optimal. Dalam penelitian ini, pemilihan titik knot optimal dilakukan dengan menggunakan metode Mean Square Eror (MSE). Adapun rumus MSE dapat dituliskan sebagai berikut:

dengan

$$
M S E=\frac{1}{n} \sum_{i=1}^{n}\left(y_{i}-\hat{f}_{\Pi i}\right)^{2}
$$

$$
\begin{array}{ll}
n & : \text { banyaknya pengamatan } \\
y_{i} & : \text { data aktual pengamatan ke-i } \\
\hat{f}_{\Pi i} & : \text { data hasil estimasi pengamatan ke-i }
\end{array}
$$

Model terbaik adalah model yang memiliki nilai MSE minimum.

\subsection{Koefisien Determinasi $\left(\mathbf{R}^{2}\right)$}

Koefisien determinasi digunakan untuk menunjukan seberapa besar persentase keragaman dalam variabel respon yang dijelaskan oleh variabel predictor (Gujarati 2004). Koefisien determinasi dapat dihitung dengan rumus berikut:

dengan

$$
R^{2}=\frac{J K R}{J K T}=1-\frac{J K G}{J K T}=1-\frac{\sum_{i=1}^{n}\left(y_{i}-\hat{y}_{i}\right)^{2}}{\sum_{i=1}^{n}\left(y_{i}-\bar{y}_{i}\right)^{2}}
$$

JKR : Jumlah Kuadrat Regresi

JKG : Jumlah Kuadrat Galat

JKT : Jumlah Kuadrat Total

\subsection{Mean Absolute Percentage Error (MAPE)}

Evaluasi hasil peramalan digunakan untuk mengetahui ketepatan hasil peramalan yang telah dilakukan terhadap data yang sebenarnya. Adapun rumus untuk menghitung MAPE sebagai berikut:

dengan

$$
M A P E=\frac{1}{n} \sum_{i=1}^{n}\left|\frac{y_{i}-\hat{y}_{i}}{y_{i}}\right| \times 100 \%
$$




$$
\begin{array}{ll}
n & \text { : banyaknya pengamatan yang diprediksi } \\
y_{i} & \text { : data aktual pada pengamatan ke-i } \\
\hat{y}_{i} & \text { : data hasil estimasi pada pengamatan ke-i }
\end{array}
$$

Menurut Chang, et al dalam Halimi, et al (2013) suatu model mempunyai kinerja sangat bagus jika nilai MAPE kurang dari $10 \%$.

\section{METODELOGI PENELITIAN}

\subsection{Jenis dan Sumber Data}

Data yang digunakan dalam penelitian ini merupakan data sekunder yaitu IHSG, Inflasi, Kurs dan suku bunga SBI. Data dalam penelitian ini dibagi menjadi dua yaitu $75 \%$ data in sample dan $25 \%$ data out sample. Data in sample digunakan dalam pembentukan model dengan periode data bulan Januari 2014 sampai dengan Desember 2016. Sedangkan, data out sample digunakan untuk peramalan dengan periode data bulan Januari 2017 sampai dengan Desember 2017. Data IHSG tersebut dapat diakses pada situs https://finance.yahoo.com/. Sedangkan untuk data Inflasi, Kurs dan suku bunga SBI diperoleh dari website https://www.bi.go.id.

\subsection{Variabel Penelitian}

Variabel respon $(\mathrm{Y})$ dan variabel prediktor $(\mathrm{X})$ yang digunakan dalam penelitian ini sebagai berikut:

$$
\begin{array}{ll}
\mathrm{Y} & \text { : Indeks Harga Saham Gabungan } \\
\mathrm{X}_{1} & \text { : Inflasi } \\
\mathrm{X}_{2} & \text { : Nilai Tukar (Kurs) } \\
\mathrm{X}_{3} & \text { : Suku Bunga Sertifikat Bank Indonesia }
\end{array}
$$

\subsection{Metode Analisis Data}

Software yang digunakan dalam penelitian ini yaitu Minitab 17, R i386 3.4 .2 dan Microsoft Excel 2013. Langkah-langkah analisis dalam penelitian ini sebagai berikut:

1. Melakukan input data variabel respon dan variabel prediktor

2. Membagi data menjadi data in sample dan out sample

3. Melakukan analisis deskriptif pada data in sample

4. Membuat scatterplot antara variabel respon terhadap masing-masing variabel prediktor

5. Menentukan orde dan titik knot yang akan dicobakan

6. Melakukan kombinasi orde dan titik knot

7. Menentukan model spline untuk setiap kombinasi orde dan titik knot

8. Menghitung nilai MSE

9. Menentukan titik knot optimal dengan nilai MSE minimum

10. Menentukan model spline terbaik

11. Menghitung nilai $\mathrm{R}^{2}$ sebagai kriteria kebaikan model

12. Menghitung nilai MAPE dari data out sampel sebagai evaluasi kinerja model.

\section{HASIL DAN PEMBAHASAN}

\subsection{Statistika Deskriptif}

Statistika Deskriptif dari setiap variabel penelitian dapat dilihat pada Tabel 1. 
Tabel 1. Statistika Deskriptif

\begin{tabular}{cllll}
\hline Variabel & $\mathbf{N}$ & Minimum & Maksimum & Rata-rata \\
\hline $\mathrm{Y}$ & 36 & 4223,91 & 5518,67 & 4957,52 \\
$\mathrm{X}_{1}$ & 36 & 2,79 & 8,36 & 5,44 \\
$\mathrm{X}_{2}$ & 36 & 11427,05 & 14396,10 & 12856,13 \\
$\mathrm{X}_{3}$ & 36 & 5,90 & 7,23 & 6,74 \\
\hline
\end{tabular}

\subsection{Scatterplot}

Analisis regresi merupakan salah satu metode statistika yang digunakan untuk menyelidiki pola hubungan antara varaiabel prediktor dengan variabel respon. Bentuk pola hubungan fungsional antara variabel prediktor dengan variabel respon dapat diperkirakan dengan membuat scatterplot yang memuat informasi tentang hubungan kedua variabel tersebut.

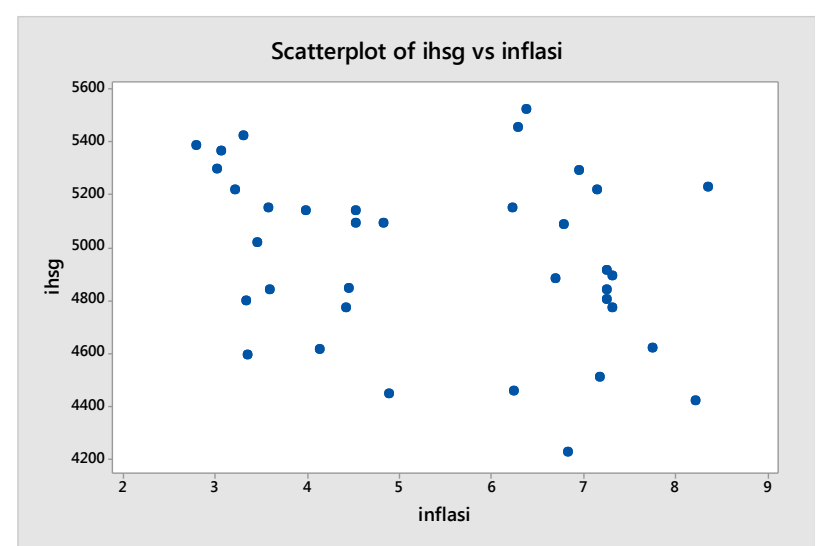

Gambar 1

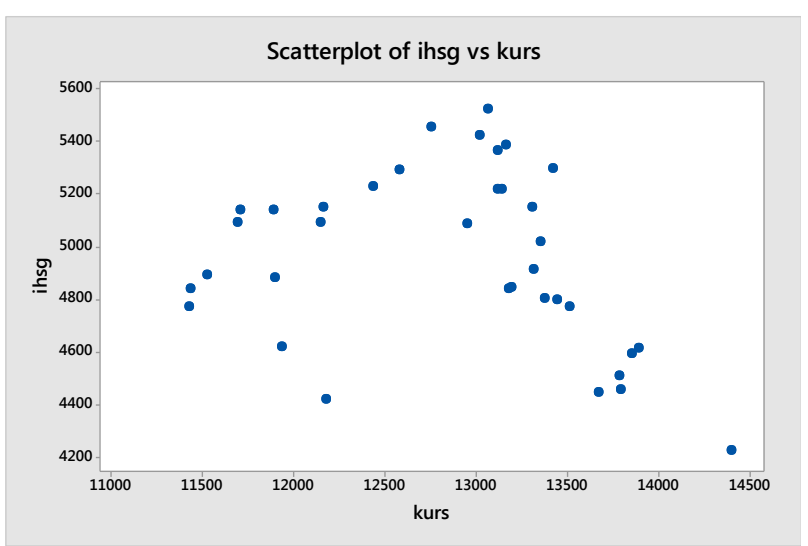

Gambar 2

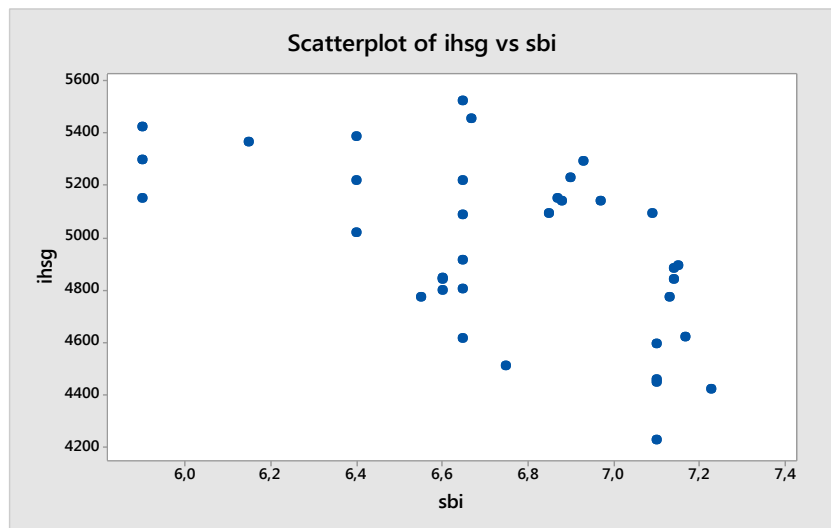

Gambar 3

Ket: Scatterplot antara variabel $\mathrm{X}_{1}$ terhadap variabel respon (Gambar 1), Scatterplot antara variabel $\mathrm{X}_{2}$ terhadap variabel respon (Gambar 2) dan Scatterplot antara variabel $\mathrm{X}_{3}$ terhadap variabel respon (Gambar 3).

Berdasarkan Gambar 1, Gambar 2 dan Gambar 3 plot antara IHSG dengan Inflasi, Kurs dan suku bunga SBI diketahui bahwa dari ketiga plot hubungan tersebut tidak ada kecenderungan pola hubungan tertentu sehingga tidak diketahui bentuk kurva regresinya. 
Oleh karena itu pendekatan yang digunakan yaitu regresi nonparametrik. Regresi nonparametrik yang digunakan yaitu regresi nonparametrik spline multivariabel.

\subsection{Pemilihan Titik Knot Optimal}

Estimasi kurva regresi menggunakan regresi spline dilakukan dengan menentukan banyak dan letak titik knot dalam beberapa orde. Banyak titik knot yang akan digunakan pada setiap variabel prediktor yaitu satu knot, dua knot dan juga kombinasi satu dan dua knot pada setiap variabel prediktor sehingga memungkinkan setiap variabel prediktor mempunyai banyak knot yang tidak sama. Letak titik knot merupakan hal yang penting untuk mendapatkan model terbaik, dalam hal ini letak titik knot ditempatkan pada titik datanya. Pada penelitian ini, metode yang digunakan untuk menentukan titik knot optimal adalah metode Mean Square Error (MSE).

\subsection{Model Spline Terbaik}

Model spline terbaik yaitu model dengan MSE minimum. Berikut nilai MSE minimum untuk masing-masing kombinasi knot dan orde.

\section{Tabel 2. Perbandingan Nilai MSE Minimum}

Berdasarkan Tabel 2 nilai MSE minimum dengan nilai 6686,85 diperoleh pada saat $X_{1}$ berorde $4, X_{2}$ berorde 2 dan X3 berorde 2 . Banyaknya knot $X_{1}$ sebanyak 1 knot yaitu pada titik 8,2 banyaknya knot $\mathrm{X}_{2}$ sebanyak 2 knot yaitu pada titik 13066,82 dan 13781,75 dan banyaknya knot $\mathrm{X}_{3}$ sebanyak 2 knot yaitu pada titik 6,6 dan 6,67 .

\begin{tabular}{|c|c|c|c|c|c|c|c|c|c|c|}
\hline \multirow[b]{2}{*}{ No } & \multicolumn{3}{|c|}{ Banyak knot } & \multicolumn{3}{|c|}{ Orde } & \multicolumn{3}{|c|}{ Titik knot } & \multirow[b]{2}{*}{ MSE } \\
\hline & $X_{1}$ & $\mathrm{X}_{2}$ & $X_{3}$ & $\mathrm{X}_{1}$ & $\mathrm{X}_{2}$ & $X_{3}$ & $\mathrm{X}_{1}$ & $X_{2}$ & $X_{3}$ & \\
\hline 1 & 1 & 1 & 1 & 4 & 2 & 2 & 6,96 & 12749,84 & 7,09 & 9711,049 \\
\hline 2 & 1 & 1 & 2 & 4 & 2 & 2 & 8,22 & 12749,84 & 6,$6 ; 6,65$ & 8142,123 \\
\hline 3 & 1 & 2 & 1 & 4 & 2 & 4 & 7,15 & $13165 ; 13179,86$ & 6,93 & 7706,509 \\
\hline 4 & 2 & 1 & 1 & 4 & 2 & 2 & 6,$25 ; 6,29$ & 12749,84 & 7,09 & 9545,308 \\
\hline 5 & 2 & 2 & 1 & 3 & 2 & 3 & 6,$29 ; 6,38$ & $13165 ; 13179,86$ & 6,97 & 7183,899 \\
\hline 6 & $\mathbf{1}$ & 2 & 2 & 4 & 2 & 2 & 8,22 & 13066,$82 ; 13781,75$ & 6,$6 ; 6,67$ & 6686,85 \\
\hline 7 & 2 & 1 & 2 & 4 & 4 & 2 & 3,$31 ; 8,22$ & 12947,76 & 6,$6 ; 6,65$ & 6878,239 \\
\hline 8 & 2 & 2 & 2 & 3 & 2 & 3 & 6,$29 ; 6,38$ & $13165 ; 13179,86$ & 6,$87 ; 6,88$ & 6757,728 \\
\hline
\end{tabular}

Model spline multivariabel dengan $\mathrm{X}_{1}$ berorde $4, \mathrm{X}_{2}$ berorde 2 dan $\mathrm{X}_{3}$ berorde 2 dengan banyaknya titik knot $\mathrm{X}_{1}$ sebanyak 1 knot, $\mathrm{X}_{2}$ sebanyak 2 knot dan banyaknya titik knot $\mathrm{X}_{3}$ sebanyak 2.

$$
\begin{array}{r}
\hat{y}=\hat{\alpha}_{00}+\hat{\alpha}_{11} x_{1}+\hat{\alpha}_{21} x_{1}^{2}+\hat{\alpha}_{31} x_{1}^{3}+\hat{\beta}_{11}\left(x_{1}-k_{11}\right)_{+}^{3}+\hat{\alpha}_{12} x_{2}+\hat{\beta}_{21}\left(x_{2}-k_{12}\right)_{+} \\
+\hat{\beta}_{22}\left(x_{2}-k_{22}\right)_{+}^{2}+\hat{\alpha}_{13} x_{3}+\hat{\beta}_{31}\left(x_{3}-k_{13}\right)_{+}+\hat{\beta}_{32}\left(x_{3}-k_{23}\right)_{+}^{2}
\end{array}
$$


Tabel 3. Estimasi Parameter Model Spline Terbaik

\begin{tabular}{crr}
\hline Variabel & Parameter & \multicolumn{1}{c}{ Estimasi Parameter } \\
\hline Intersep & $\hat{\alpha}_{00}$ & 58,747 \\
\hline $\mathrm{X}_{1}$ & $\hat{\alpha}_{11}$ & $-46,72$ \\
& $\hat{\alpha}_{21}$ & 32,912 \\
& $\hat{\alpha}_{31}$ & $-7,6$ \\
& $\hat{\beta}_{11}$ & 377,127 \\
\hline $\mathrm{X}_{2}$ & $\hat{\alpha}_{12}$ & 1,128 \\
& $\hat{\beta}_{21}$ & $-1,03$ \\
& $\hat{\beta}_{22}$ & 2,45 \\
\hline $\mathrm{X}_{3}$ & $\hat{\alpha}_{13}$ & $-31,865$ \\
& $\hat{\beta}_{31}$ & 119,861 \\
& $\hat{\beta}_{32}$ & $-124,825$ \\
\hline
\end{tabular}

Berdasarkan Tabel 3 maka diperoleh estimasi model spline multivariabel terbaik sebagai berikut:

$$
\begin{aligned}
\hat{y}= & 58,747-46,72 x_{1}+32,912 x_{1}^{2}-7,6 x_{1}^{3}+377,127\left(x_{1}-8,22\right)_{+}^{3}+1,128 x_{2}- \\
& 1,03\left(x_{2}-13066,82\right)_{+}+2,45\left(x_{2}-13781,75\right)_{+}^{2}-31,865 x_{3}+119,861\left(x_{3}-\right. \\
& 6,6)_{+}-124,825\left(x_{3}-6,67\right)_{+}^{2} \\
\hat{y}= & 58,747+f_{1}\left(x_{1}\right)+f_{2}\left(x_{2}\right)+f_{3}\left(x_{3}\right)
\end{aligned}
$$

dengan

$$
\begin{gathered}
f_{1}\left(x_{1}\right)=-46,72 x_{1}+32,912 x_{1}^{2}-7,6 x_{1}^{3}+377,127\left(x_{1}-8,22\right)_{+}^{3} \\
f_{1}\left(x_{1}\right)=\left\{\begin{array}{r}
-46,72 x_{1}+32,912 x_{1}^{2}-7,6 x_{1}^{3}, \\
-46,72 x_{1}+32,912 x_{1}^{2}-7,6 x_{1}^{3}+377,127\left(x_{1}-8,22\right)^{3}, x_{1} \geq 8,22
\end{array}\right. \\
f_{2}\left(x_{2}\right)=1,128 x_{2}-1,03\left(x_{2}-13066,82\right)_{+}+2,45\left(x_{2}-13781,75\right)_{+}^{2} \\
f_{2}\left(x_{2}\right)= \begin{cases}1,128 x_{2} & , x_{2}<13066,82 \\
1,128 x_{2}-1,03\left(x_{2}-13066,82\right) & , 13066,82 \leq x_{2}<13781,75 \\
1,128 x_{2}-1,03\left(x_{2}-13066,82\right)+2,45\left(x_{2}-13781,75\right)^{2} & , x_{2} \geq 13781,75\end{cases} \\
f_{3}\left(x_{3}\right)=31,865 x_{3}+119,861\left(x_{3}-6,6\right)_{+}-124,825\left(x_{3}-6,67\right)_{+}^{2} \\
f_{3}\left(x_{3}\right)=\left\{\begin{array}{cc}
31,865 x_{3} & , x_{3}<6,6 \\
31,865 x_{3}+119,861\left(x_{3}-6,6\right) & , x_{3}<6,67 \\
31,865 x_{3}+119,861\left(x_{3}-6,6\right)_{+}-124,825\left(x_{3}-6,67\right)^{2} & , x_{3} \geq 6,67
\end{array}\right.
\end{gathered}
$$

Diperoleh hasil estimasi data aktual dan prediksi pada data in sample yang disajikan pada Gambar 4. 


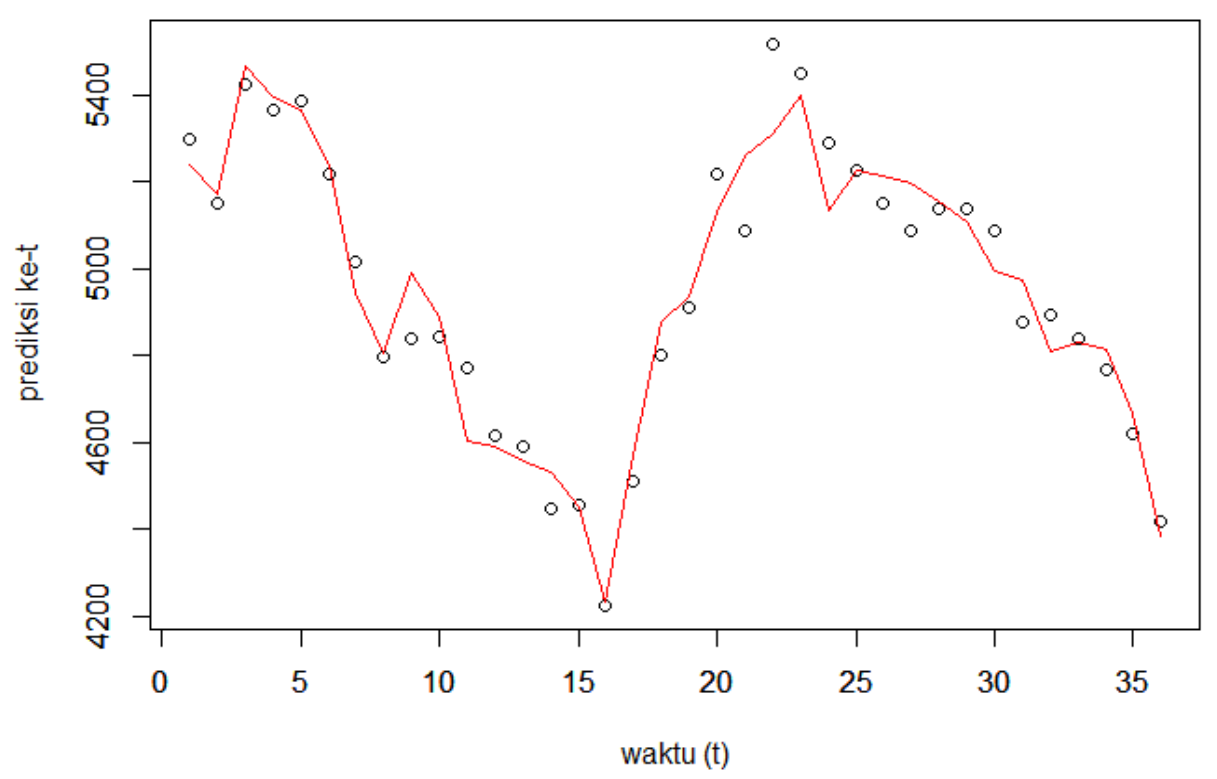

Gambar 4. Komparasi data aktual dan data prediksi pada data in sample

Pada Gambar 4 dapat dilihat bahwa estimasi yang dihasilkan mendekati sebaran data aktualnya. Hal tersebut menunjukkan bahwa regresi spline memiliki kemampuan menyesuaikan diri lebih efektif terhadap pola data yang naik atau turun secara tajam dengan bantuan titik-titik knot, serta kurva yang dihasilkan relatif mulus.

\subsection{Koefisien Determinasi $\left(\mathbf{R}^{2}\right)$}

Diperoleh nilai koefisien determinasi sebagai berikut:

$$
\begin{aligned}
& R^{2}=\frac{J K R}{J K T}=\frac{\sum_{i=1}^{n}(\hat{y}-\bar{y})^{2}}{\sum_{i=1}^{n}(y-\bar{y})^{2}}=\frac{(5240,054-4957,52)^{2}+(5172,417-4957,52)^{2}+\cdots+(4383,053-4957,52)^{2}}{(5296,71-4957,52)^{2}+(5148,91-4957,52)^{2}+\cdots \ldots . .+(4418,76-4957,52)^{2}} \\
& R^{2}=0,9371
\end{aligned}
$$

Nilai $\mathrm{R}^{2}$ tersebut menunjukkan bahwa pengaruh inflasi, kurs dan suku bunga SBI terhadap IHSG sebesar 93,71\%.

\subsection{Mean Absolute Percentage Error (MAPE)}

MAPE digunakan pada data out sample dan diperoleh hasil sebagai berikut:

$M A P E=\frac{1}{n} \sum_{i=1}^{n}\left|\frac{y_{i}-\hat{y}_{i}}{y_{i}}\right| x 100 \%=\frac{1}{12}\left(\left|\frac{5294,1-5392,543}{5294,1}\right|+\cdots+\left|\frac{6355,65-6241,379}{6355,65}\right|\right) \times 100 \%$ $M A P E=1,688 \%$

Nilai MAPE kurang dari 10\% maka dapat disimpulkan bahwa estimasi model spline terbaik mempunyai kemampuan peramalan yang sangat baik.

\section{KESIMPULAN}

Berdasarkan analisis yang telah dilakukan, maka dapat diambil beberapa kesimpulan antara lain:

1. Model spline terbaik untuk analisis data IHSG adalah model regresi spline $\mathrm{X}_{1}$ berorde

$4, X_{2}$ berorde 2 dan $X_{3}$ berorde 2 . Sedangkan, banyaknya knot $X_{1}$ sebanyak 1 knot yaitu pada titik 8,22, banyaknya knot $\mathrm{X}_{2}$ sebanyak 2 knot yaitu pada titik 13066,82 dan 
13781,75 serta banyaknya knot $\mathrm{X}_{3}$ sebanyak 2 knot yaitu pada titik 6,6 dan 6,67 dengan nilai MSE sebesar 6686,85.

2. Persamaan model spline terbaik adalah sebagai berikut:

$$
\begin{aligned}
\hat{f}(x)= & 58,747-46,72 x_{1}+32,912 x_{1}^{2}-7,6 x_{1}^{3}+377,127\left(x_{1}-8,22\right)_{+}^{3}+ \\
& 1,128 x_{2}-1,03\left(x_{2}-13066,82\right)_{+}+2,45\left(x_{2}-13781,75\right)_{+}^{2}- \\
& 31,865 x_{3}+119,861\left(x_{3}-6,6\right)_{+}-124,825\left(x_{3}-6,67\right)_{+}^{2}
\end{aligned}
$$

\section{DAFTAR PUSTAKA}

Astuti, R., Apriatni, E.P., dan Hari, S. 2013. Analisis Pengaruh Tingkat Suku Bunga (SBI), Nilai Tukar (Kurs) Rupiah, Inflasi, dan Indeks Bursa Internasional Terhadap IHSG (Studi pada IHSG di BEI Periode 2008-2012). Diponegoro Journal of Social and Politic of Science. Hal 1-8.

Budiantara, I.N. 2005. "Model Keluarga Spline Polinomial Truncated dalam Regresi Semiparametrik". Berkala MIPA. 15(3), September 2005.

Eubank, R. L. 1999, Nonparametric Regression and Spline Smoothing. Marcel Deker, New York.

Gujarati, D. 2004. Basic Econometrics, Fourth Edition. New York. The McGraw-Hill Companies, New York.

Halimi, R., Anggreani, W., dan Tyasnurita, R. 2013. Pembuatan Aplikasi Peramalan Jumlah Permintaan Produk dengan Metode Time Series Exponential Smoothing Holt Winter di PT. Telekomunikasi Indonesia Tbk. Jurnal Teknik POMITS, Vol.1, No.1.

Hardle, W. 1990. Applied Nonparametric Regression. Cambridge University Press, NewYork.

Martalena dan Maya. 2011. Pengantar Pasar Modal. Andi Yogyakarta, Jakarta.

Salvatore, D. 2014. Ekonomi Internasional. Salemba Empat, Jakarta.

Samsul, M. 2006. Pasar Modal dan Manajemen Portofolio. Erlangga, Surabaya.

Wijaya, J.T. 2015. Faktor-Faktor yang Mempengaruhi Nilai IHSG yang Terdaftar di Bursa Efek Indonesia. Jurnal Ilmu dan Riset Manajemen Vol.4, No.6, Juni 2015. 